\title{
The Effect of Job Involvement and Work Stress on Turnover Intention with Organizational Commitment as an Intervening Variable PT. Perkebunan Minanga Ogan
}

\author{
Meili Bugis; Dedi Purwana E.S; Saparuddin \\ Department of Master Management, Universitas Negeri Jakarta, Indonesia \\ http://dx.doi.org/10.18415/ijmmu.v8i9.3033
}

\begin{abstract}
The purpose of this study was to determine the effect of work involvement and work stress on the turnover intention with organizational commitment as an intervening variable at PT. Perkebunan Minanga Ogan. The approach used in this research is quantitative. To determine the sample using probability sampling, then probability sampling used is simple random sampling. The sample in this study were contract employees totaling 200 people at PT. Perkebunan Minanga Ogan. The analytical method used to determine the relationship between these variables is path analysis using the structural equation model (SEM) method and the AMOS program. The results of hypothesis testing are as follows: the work involvement variable has a positive and insignificant effect on organizational commitment. The job stress variable harms organizational commitment. The organizational commitment variable has a positive and significant effect on turnover intention. Job involvement variable harms turnover intention. The job stress variable has a positive and significant effect on turnover intention. Job involvement has a positive and significant effect on the turnover intention with organizational commitment as an intervening variable and work stress has a negative and significant effect on the turnover intention with organizational commitment as an intervening variable.
\end{abstract}

Keywords: Job Involvement; Job Stress; Turnover Intention; Organizational Commitment

\section{Introduction}

Human resources are an important asset for the company to carry out all previously planned activities and are very valuable for the company to create company goals, success or failure of the company, one of the factors that determine is the individual aspect (Tulangow et al, 2018). The activities of poor human resource management can cause big losses, such as an increase in the willingness of employees to leave their jobs or turnover intention. Continuous turnover can make it difficult for the company because the company has run out of employees and these losses must be replaced with new employees (Tnay et al., 2013). Turnover Intention or the desire to leave the company has been described as an effort or willingness of employees to voluntarily leave their workplace (Takase, 2010).

According to (Tnay et al., 2013) if in the area of activity, the essential case of employee turnover has increased beyond normal. This is explained by the observations of the Hay Group regarding the overall

The Effect of Job Involvement and Work Stress on Turnover Intention with Organizational Commitment as an Intervening Variable PT.

Perkebunan Minanga Ogan 
level of employee turnover which is always increasing (Hay Group Survey Results Information, 2014). If in 2010-2018 the turnover rate in the country experienced a fairly relevant increase every year. A very large overall rate of employee turnover took place in 2014, with the most development taking place that year. In addition, in general, the turnover ratio in the next 5 years will increase to $23.4 \%$. After that, in the regional scope, the percentage of turnover rates obtained from the Hay Group survey results where Indonesia with a percentage of $25.8 \%$ succeeded in climbing to the 3 rd level of the country with the highest employee turnover rate compared to Brazil (24.4\%), US (21.8\%). ), China (21.3\%), and the UK (14.6\%).

In the industry, turnover is felt by PT. Perkebunan Minanga Ogan. Total turnover at PT. Perkebunan Minanga Ogan, the period of 2015-2018 is said to be large, this is based on the statement (Gillies, 1989) which explains that employee rotation is considered reasonable, ranging from 5-10\% per year and is called large if more than $10 \%$ per year. The number of turnovers that took place at PT. Perkebunan Minanga Ogan, in 2015 it was $20 \%$ or 224 employees, in 2016 it was $24 \%$ or 268 employees, in 2017 it was $19 \%$ or 206 employees and in 2018 it was $37 \%$ or 414 employees. If you observe the information above, it appears that the Turnover Intention value escalation in the last 4 years duration, where a very relevant Turnover Intention escalation took place in the 2017 to 2018 duration span of $18 \%$.

Many aspects are quite important that can influence a person's desire to leave the agency in search of the latest agency so that in this research the observer carried out a pre-survey to identify what variables for respondents had an impact on Turnover Intention. The results of the pre-survey questionnaire state that there are three lowest variables, namely work involvement with a total score of 238 or $91 \%$, work stress with a total score of 231 or $88 \%$, and organizational commitment with a total score of 239 or $91 \%$ which has the lowest percentage so that it makes the variable this is problematic. One influential aspect that causes employees' willingness to switch is the presence of work involvement (Kanungo, 1982). Work involvement is a part where the person is known from his profession, participates actively in it, and thinks the performance is meaningful for self-esteem (S. P. Robbins, 2013).

According to (Robbins, SP, 2014) Another aspect that affects Turnover Intention is work stress. Work stress is a feeling of being squeezed by employees in their careers (Mangkunegara, 2013). The impact of stress-related attitudes includes changes in creativity, large employee turnover, high absenteeism levels, and accidents at work (Robbins, SP, 2014). Another aspect that influences Turnover Intention is organizational commitment ( Mobley, 1978) Organizational commitment is a trust that binds employees to the institution where they work, which is indicated by the presence of compliance, participation in careers, and an introduction to the values and goals of the organization (Meyer, 1997).

\section{Research Method}

This research was conducted at PT. Perkebunan Minanga Ogan. The type of research used in this study is quantitative, using a causal relationship, namely research designed to examine the effect of one variable on other variables. The population in this study were all contract employees at PT. Perkebunan Minanga Ogan. To determine the number of samples in this study using probability sampling, probability sampling used is simple random sampling. In this study, the number of samples is 200 contract employees at PT.Perkebunan Minanga Ogan. The data collection technique in this research is a questionnaire. The type of data used in this study is qualitative data which is then converted into quantitative data in the form of scores or numbers obtained from respondents' answers to the questionnaire. In conducting data analysis in this study, researchers used structural equation model analysis (SEM) techniques from the AMOS statistical software package, namely in model formation and hypothesis testing. 


\section{Results and Discussion}

\section{Structural Equation Modeling Analysis}

Data analysis in this study used Structural Equation Modeling (SEM). In SEM analysis, two stages of analysis must be carried out, namely first, testing the factors that make up each variable, where testing is carried out using a confirmatory factor analysis model and the second is testing regression weights in full model analysis.

\section{Confirmatory Factor Analysis}

The Confirmatory Factor Analysis Covariance test was carried out using the goodness of fit value criterion. The data can be said to be fit and further analysis can be done if all the calculation value criteria meet the goodness of fit criteria. Figure 1 shows the Confirmatory Factor Analysis (CFA) test model associated with all variables in the study, including work involvement (KT) 11 statements, work stress (SK) 10 statements, turnover intention (TI) 4 statements, and organizational commitment (KO). 15 statements.

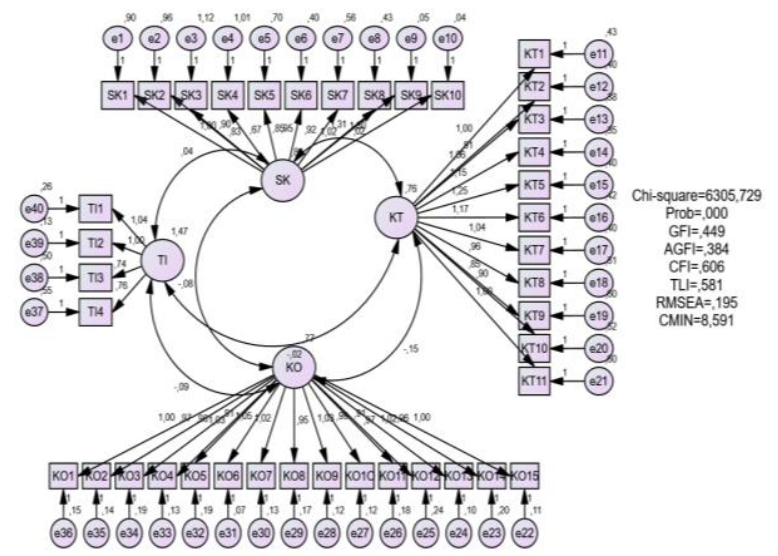

Figure 1. The Confirmatory Factor Analysis (CFA) test model associated with all variables in the study

From the picture above, it can be seen that confirmatory factor analysis (CFA) has not met the criteria for the goodness of fit confirmatory factor analysis (CFA) that have been set. One method to see the source of unfit results is to look at modification indices (Byrne, 2001). Modification Indices will show the number of correlated indicator errors. Error rates that have a large relationship can be linked or removed from the analysis (Jöreskog and Sörbom, 1996).

In this case, indicators that have a high error are removed from the analysis. In the work involvement variable, the indicators dropped from the analysis include KT2, KT3, KT5, KT6, KT8, KT9, KT11. Then the work stress indicators that were dropped from the analysis included: SK1, SK2, SK4, SK5, SK7, SK8. Furthermore, the Turnover Intention indicator variable that was dropped from the analysis was TI1 and the indicator organizational commitment variable that was dropped from the analysis included: KO1, KO2, KO3, KO4, KO5, KO8, KO10, KO11, KO12, KO13, KO14. 


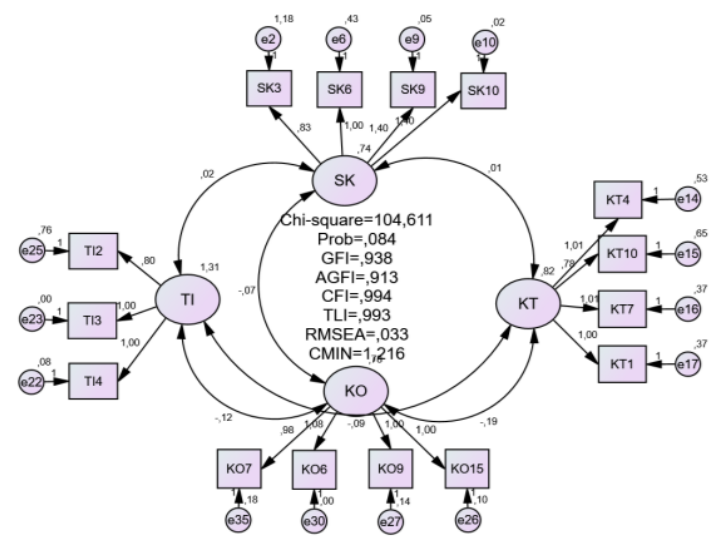

Figure 2. The Confirmatory Factor Analysis (CFA) test model (preferred indicator)

From the picture above, it can be seen that confirmatory factor analysis (CFA) has met the criteria for the goodness of fit confirmatory factor analysis (CFA) that have been determined. Because all the criteria in the goodness of fit confirmatory factor analysis (CFA) have been met, the data can be analyzed further.

\section{Goodness of Fit}

The model suitability test was conducted to find out that the research model that was created had met the goodness of fit criteria so that the research model that was created could be analyzed further. The following is the model suitability test in this study.

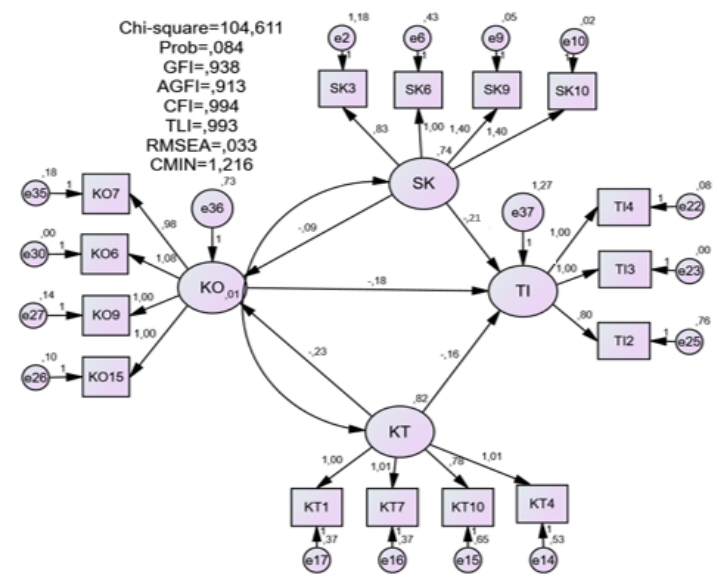

Figure 3. The model suitability test in this study

Based on the picture above, table 1 shows summarizes the criteria for the Goodness of fit research model.

Table 1. The summarizes the criteria for the Goodness of fit research model

\begin{tabular}{|l|c|c|c|}
\hline The goodness of fit index & Cut-Off Value & Result & Model Evaluation \\
\hline Chi-square $\left(\mathrm{X}^{2}\right)$ & Expected small & 104.611 & fit \\
\hline Significance probability $(\mathrm{p})$ & $\geq 0.05$ & 0.084 & Good fit \\
\hline GFI & $>0.90$ & 0.938 & Good fit \\
\hline AGFI & $\geq 0.90$ & 0.913 & Good fit \\
\hline CFI & $>0.90$ & 0.994 & Good fit \\
\hline NNFI/TLI & $>0.90$ & 0.993 & Good fit \\
\hline RMSEA & $\leq 0.08$ & 0.033 & Good fit \\
\hline CMIN/DF & $\leq 2.00$ & $\mathrm{I} .216$ & Good fit \\
\hline
\end{tabular}


The results from the table above show that all the criteria for the goodness of fit have been met, so it can be said that the model in the figure can be further analyzed to test the hypothesis.

\section{Hypothesis test}

The seven hypothesis tests in this study were carried out by looking at the t-value, which is the critical ratio (CR) value on the regression weight with the condition that if the value is 1.96 and with a probability value of less than 0.05 , the research hypothesis in this study can be accepted.

Table 2. The seven hypothesis tests in this study

\begin{tabular}{|c|c|c|c|c|c|}
\hline Hypothesis & Estimate & S.E. & C.R. & P & Results \\
\hline H1 & -.231 & .073 & 3.154 & .002 & Accepted \\
\hline H2 & -.088 & .072 & 1.234 & .217 & Rejected \\
\hline H3 & -.185 & .094 & 1.965 & .049 & Accepted \\
\hline H4 & -.156 & .098 & 1.587 & .112 & Rejected \\
\hline H5 & -.213 & .094 & 3.139 & .004 & Accepted \\
\hline
\end{tabular}

In general, testing this hypothesis is done by looking at the critical ratio (CR) and p-value of the significance of the data processing results compared to the required statistical limits. Related to the first objective of the study which states that this study aims to analyze and determine the significance of the effect of work involvement on organizational commitment, which then forms the first hypothesis, namely that work involvement has a positive and insignificant effect on organizational commitment. This can be seen in the critical ratio (CR) which is above $1.96(>1.96)$ and the probability value which is below 0.05 $(<0.05)$.

Related to the second research objective which states that this study aims to analyze and determine the significance of the effect of work stress on organizational commitment, which then forms the second hypothesis, namely that work stress harms organizational commitment. This can be seen in the critical ratio $(\mathrm{CR})$ which is below $1.96(<1.96)$ and the probability value is above $0.05(>0.05)$. This proves that the higher the employee's work stress level, the lower the organizational commitment and vice versa.

Related to the third research objective which states that this study aims to analyze and determine the significance of the effect of organizational commitment on turnover intention, which then forms the third hypothesis, namely organizational commitment has a positive and significant effect on turnover intention. This can be seen in the critical ratio $(\mathrm{CR})$ which is below $1.96(<1.96)$ and the probability value is above $0.05(>0.05)$.

Related to the fourth research objective which states that this study aims to analyze and determine the significance of the effect of work involvement on turnover intention, which then forms the fourth hypothesis, namely work involvement harms turnover intention. This can be seen in the critical ratio (CR) which is above $1.96(>1.96)$ and the probability value which is below $0.05(<0.05)$.

Related to the fifth research objective which states that this study aims to analyze and determine the significance of the effect of work stress on turnover intention, which then forms the fifth hypothesis, namely that work stress has a positive and significant effect on turnover intention. This can be seen in the critical ratio (CR) which is above $1.96(>1.96)$ and the probability value which is below $0.05(<0.05)$.

\section{Sobel Test}

In this study to test the indirect effect using the Sobel test with the results: 
Related to the sixth research objective which states that this study aims to analyze and determine the significance of the effect of work involvement on turnover intention through organizational commitment as an intervening variable, which then forms the sixth hypothesis, namely work involvement has a positive and significant effect on the turnover intention with organizational commitment as an intervening variable.

These results can be seen in the Sobel test showing a statistical value ( $\mathrm{z}$ value analysis results) for the influence of the organizational commitment variable as an intervening variable between job involvement and turnover intention variables 2.14081271 and significant on the two-tailed probability with several 0.03 . Because $\mathrm{z}$-value $>1.96$ or $\mathrm{p}$-value $<\mathrm{a}=0.05$, it can be concluded that the indirect effect is significant, so the mediation hypothesis is supported.

Related to the seventh research objective which states that this study aims to analyze and determine the significance of the effect of work stress on turnover intention through organizational commitment as an intervening variable, which then forms the seventh hypothesis, namely work stress has a negative and significant effect on the turnover intention with organizational commitment as an intervening variable.

These results can be seen in the Sobel test showing the statistical value ( $\mathrm{z}$ value analysis results) for the influence of the organizational commitment variable as the intervening variable between the work stress variable and Turnover Intention 0.3606780 and significant on the two-tailed probability with the number 0.07 . Because $z$-value $<1.96$ or $\mathrm{p}$-value $>\mathrm{a}=0.05$, it can be concluded that the mediation hypothesis is not supported.

\section{Conclusion}

Based on the description of the research results and discussion in the previous chapter, the results of the study can be concluded that: 1 . Work involvement has a positive and insignificant effect on commitment. These results prove that the higher the number of employees involved in a job, the higher the level of employee performance, which means that the higher the priority in the work, the higher the work involvement. This means that the higher the level of employee work involvement will increase organizational commitment to employees. 2. Job stress harms organizational commitment. This proves that the higher the employee's work stress level, the lower the organizational commitment and vice versa. 3 . Organizational commitment has a positive and significant effect on turnover intention. This proves that the higher the organizational commitment, the lower the level of employee turnover. 4. Work involvement harms turnover intention. This proves that the lower the level of employee involvement, the higher the turnover intention. 5. Job stress has a positive and significant effect on turnover intention. This proves that the higher the employee's work stress level, the higher the turnover intention. 6. Job involvement has a positive and significant effect on the turnover intention with organizational commitment as an intervening variable. It can be concluded that the indirect effect is significant, so the mediation hypothesis is supported. This proves that the organizational commitment variable can mediate work involvement on turnover intention. 7. Job stress has a negative and significant effect on the turnover intention with organizational commitment as an intervening variable. It can be concluded that the mediation hypothesis is not supported. This proves that the organizational commitment variable is not able to mediate employee work stress on turnover intention.

\section{References}

Agus, I. K., Sentana, D., Bagus, I., \& Surya, K. (2017). Pengaruh Kepuasan Kerja Dan Komitmen Organisasional Terhadap Turnover Intention. Fakultas Ekonomi dan Bisnis Universitas Udayana ( Unud ), Bali. 6(10), 5232-5261.

Al-ghamdi, N. G. (2017). Role Overload and Job Stress among the Female University Teachers- Saudi Context. 6(2), 288-295.

The Effect of Job Involvement and Work Stress on Turnover Intention with Organizational Commitment as an Intervening Variable PT. 
Arianto, A., \& . S. (2018). The Influence of Reward on Turnover Intention with the Organizational Commitment as an Intervening Variable (A Study on Group I and II Employee at Djatiroto Sugar Factory). KnE Social Sciences, 3(3), 308. https://doi.org/10.18502/kss.v3i3.1891

Arikunto, S. (2010). Prosedur Penelitian: Suatu Pendekatan Praktik. Jakarta: Rineka Cipta.

Arshadi, N., \& Damiri, H. (2013). The relationship of job stress with turnover intention and job performance: Moderating role of OBSE. Procedia-Social and Behavioral Sciences. https://www.sciencedirect.com/science/article/pii/S1877042813017059

Asih yuli gusti et al. (2018). Stress Kerja (Pertama). Semarang: University Press.

Blau, G. J., \& Boal, K. B. (1987). Conceptualizing How Job Involvement and Organizational Commitment Affect Turnover and Absenteeism. Academy of Management Review, 12(2), 288-300. https://doi.org/10.5465/amr.1987.4307844

Booth, S., \& Hamer, K. (2007). Labour turnover in the retail industry: Predicting the role of individual, organisational and environmental factors. International Journal of Retail and Distribution Management, 35(4), 289-307. https://doi.org/10.1108/09590550710736210

Byrne, B. M. (2001). Structural Equation Modeling With AMOS, EQS, and LISREL: Comparative Approaches to Testing for the Factorial Validity of a Measuring Instrument. International Journal of Testing, 1(1), 55-86. https://doi.org/10.1207/s15327574ijt0101_4

Chairiza, D. et al. (2018). Pengaruh Burnout dan Employee Engagement terhadap Intensi Turnover Karyawan Hotel The Influence of Burnout and Employee Engagement toward Employee Turnover Intention of Hotel Employee. Magister, Jurnal Uma, Psikologi, 10(2), 69-79.

Colquitt, et al. (2009). Organizational Behavior Improving Performance And Commitment In The Workplace. New York: Mc Graw Hi.

Donni juni priansa. (2017). perencanaan dan pengembangan SDM. Bandung : Alfabeta.

Eduardo Salas, et al. (2013). Theories of team cognition: cross-disciplinary perspectives. Theories of Team Cognition: Cross-Disciplinary Perspectives, 177, 1-638. https://doi.org/10.4324/9780203813140

Faisal al madi, et all. (2017). The Impact of Employee Motivation on Organizational Commitment. July.

Fatmawati, F. (2017). Analisis Pengaruh Kompensasi, Beban Kerja, Dan Stres Kerja Terhadap Komitmen Organisasional (Studi Pada Tenaga Pemasar Mikro Pt Bank Rakyat Indonesia (Persero) Tbk, Cabang Praya). Jmm Unram - Master of Management Journal, 6(1). https://doi.org/10.29303/jmm.v6i1.34

Gibson, et al. (2010). Organisasi Manajemen (Terjemahan). Jakarta : Erlangga.

Gillies, D. A. (1989). Manajemen Keperawatan: Suatu Pendekatan Sistem (D. Sukmana (ed.); 2nd ed.). WB Saunders Company.

Gok, O. A. (2017). The Effects of Job Stress and Perceived Organizational Support on Turnover Intentions of Hotel Employees. Journal of Tourismology, 3(2), 23-32.

Hakim, A. L. et al. (2018). The Effect of Work Stress on Turnover Intention with Work Satisfaction and Commitment as Intervening Variable ( Study at PT Infomedia Solusi Humanika in Malang ). European Journal of Business and Management, 10(12), 85-94.

Handoko, H. T. (2001). Manajemen Personalia dan Sumber Daya Manusia. Yogyakarta : BPFE.

Henky Latan. (2013). Model Persamaan Struktural, Teori dan Implementasi AMOS 21,0. Bandung: Alfabeta.

Hervina, E. (n.d.). Pengaruh Kepuasan Kerja Dan Komitmen Organisasi Terhadap Intensitas Keluar Pada Cv. Karya Hidup Sentosa Medan Ester Hervina. 718-735.

Homburg, V., van der Heijden, B., \& Valkenburg, L. (2013). Why do nurses change jobs? An empirical study on determinants of specific nurses' post-exit destinations. Journal of Nursing Management, 21(6), 817-826. https://doi.org/10.1111/jonm.12142

Hung, L. M., Lee, Y. S., \& Lee, D. C. (2018). The moderating effects of salary satisfaction and working pressure on the organizational climate, organizational commitment to turnover intention. International Journal of Business and Society, 19(1), 103-116.

Izzaty, A. D., \& Nurfitriani, M. (2021). Pengembangan Media Pembelajaran Permainan Ludo Pada Materi Operasi Pengurangan Kelas 3 MIS Sindangraja. Buana Pendidikan: Jurnal Fakultas Keguruan dan Ilmu Pendidikan, 17(1), 33-41.

Kanungo, R. N. (1982). Measurement of job and work involvement. Journal of Applied Psychology, 67(3), 341-349. https://doi.org/10.1037/0021-9010.67.3.341

The Effect of Job Involvement and Work Stress on Turnover Intention with Organizational Commitment as an Intervening Variable PT.

Perkebunan Minanga Ogan 
Khaidir, M., \& Sugiati, T. (2016). "Pengaruh Stres Kerja, Kompensasi Dan Kepuasan Kerja Terhadap Turnover Intention Studi Pada Karyawan Kontrak Pt. Gagah Satria Manunggal Banjarmasin.” Jurnal Wawasan Manajemen, 4(3), 175-185.

Khatibi, A., Asadi, H., \& Hamidi, M. (2009). The Relationship Between Job Stress and Organizational Commitment in National Olympic and Paralympic Academy. World Journal of Sport Sciences, 2(4), 272-278.

Kholiq, D. A., \& Miftahuddin, M. (2019). Effect Of Job Embeddedness, Job Satisfaction, And Organizational Commitment On Employee Turnover Intention. TAZKIYA: Journal of Psychology, 5(1), 47-55. https://doi.org/10.15408/tazkiya.v22i1.8154

Kundu, S. C., \& Gahlawat, N. (2015). Socially responsible HR practices and employees' intention to quit: The mediating role of job satisfaction. Human Resource Development International, 18(4), 387-406. https://doi.org/10.1080/13678868.2015.1056500

Kuntary ibrahim, I. D. (2017). Pengaruh Stres Kerja Terhadap Turnover Intentions Yang Dimediasi Oleh Burnout" (Studi Pada Karyawan Hotel Bintang 4 (Empat) Di Kota Mataram). Jmm Unram - Master of Management Journal, 6(2), 1-16. https://doi.org/10.29303/jmm.v6i2.103

L, F., D.J, M., K.A, M., \& C, L. (2004). How can managers reduce employee intention to quit? Journal of Managerial Psychology, 19(2), 170-187.

Labrague, L. J., McEnroe - Petitte, D. M., Tsaras, K., Cruz, J. P., Colet, P. C., \& Gloe, D. S. (2018). Organizational commitment and turnover intention among rural nurses in the Philippines: Implications for nursing management. International Journal of Nursing Sciences, 5(4), 403-408. https://doi.org/10.1016/j.ijnss.2018.09.001

Li, Y., \& Jones, C. B. (2013). A literature review of nursing turnover costs. Journal of Nursing Management, 21(3), 405-418. https://doi.org/10.1111/j.1365-2834.2012.01411.x

Lu, Y., Hu, X. M., Huang, X. L., Zhuang, X. D., Guo, P., Feng, L. F., Hu, W., Chen, L., Zou, H., \& Hao, Y. T. (2017). The relationship between job satisfaction, work stress, work-family conflict, and turnover intention among physicians in Guangdong, China: A cross-sectional study. BMJ Open, 7(5), 1-12. https://doi.org/10.1136/bmjopen-2016-014894

Luthans, F. (2006). Perilaku Organisasi (Terjemahan). Yogyakarta : ANDI.

Mahnim Pane et al. (2021). Pengaruh komitmen organisasi, lingkungan kerja dan kepuasan kerja terhadap intensi turnover pegawai pada dinas perikanan kota tanjungbalai 1. 3(1), 78-87.

Mangkunegara, et al. (2013). Manajemen Sumber Daya Manusia Perusahaan. Bandung: PT Remaja Rosdakarya.

Maryati, T., \& Kusumayuda, A. (2021). Empirical Study of Job Stress, Turnover Intention, and Job Involvement. Proceedings of the 4th International Conference on Sustainable Innovation 2020Accounting and Management (ICoSIAMS 2020), 176(ICoSIAMS 2020), 50-57. https://doi.org/10.2991/aer.k.210121.008

McShane, G. (2000). Organizational Behavior. USA : McGRAW- Hil Companies, Inc.

Memon, M. A., Rohani, S., Shahrina, M. N., Jun-Hwa, C., Hiram, T., \& Francis, C. (2018). Personorganisation fit and turnover intention: The mediating role of work engagement. Journal of Management Development, 25(8).

Meyer, A. (1990). The measurement and antecedents of affective, continuance and normative commitment to the organization. Journal of Occupational Psychology, 63(1), 1-18. https://doi.org/10.1111/j.20448325.1990.tb00506.x

Meyer, A. (1997). Commitment to Organizations and Accuption: Extension and Test of Three Component Conceptualization. Journal of Applied Psychology, 78(4), 538-551.

Mobley. (1978). The relationship between human resource practices and Employee retention in public organisations: anexploratory Study conducted in the united arab emirates. International Journal of Business and Social Science.

Mobley, W. H. (2011). Pergantian Karyawan: Sebab Akibat dan Pengendaliannya. In PT Pustaka Binaman Pressindo. Jakarta: PT. Pustaka Binaman Persindo.

Nurjanah, N., \& Cahyana, U. (2021). Pengaruh Penerapan Online Project Based Learning Dan Berpikir Kreatif Terhadap Keterampilan Proses Sains Siswa Kelas IV Pada Pelajaran IPA Di SD Nasional 1 Kota Bekasi. Buana Pendidikan: Jurnal Fakultas Keguruan dan Ilmu Pendidikan, 17(1), 51-58. 
Nurlaini, N., \& Almasdi, A. (2020). Pengaruh Budaya Organisasi Dan Keterlibatan Kerja Terhadap Kinerja Karyawan Dengan Komitmen Organisasi Sebagai Variable Intervening Pada Pt Xyz. Jurnal PROFITA: Akuntansi Dan Bisnis, 1(2), 101-119. https://doi.org/10.47896/ab.v1i2.302

Nursyamsi, I. (2012). Pengruh Kepemimpinan, Pemberdayaan, dan Stres Kerja Terhadap Komitmen Organisasional serta dampaknya terhadap Kinerja Dosen. Proceedings of Conference In Business, Accounting and Management, 1(1), 405-423. lppm-unissula.com

Pool, S. W. (2000). Organizational culture and its relationship between job tension in measuring outcomes among business executives. Journal of Management Development, 19(1), 32-49. https://doi.org/10.1108/02621710010308144

Pranata, G. D., Salit, I. G., \& Netra, K. (2019). Pengaruh Stres Kerja Terhadap Turnover Intention Melalui Mediasi Komitmen Organisasional Pada Restoran Queen's Tandoor Seminyak. E-Jurnal Manajemen, $8(6), 3531-3559$.

Priyatno, D. (2009). SPSS Untuk Analisis Korelasi, Regresi Dan Multivariate. Yogyakarta: Gava Media.

Rabinowitz, S., \& Hall, D. T. (1977). Organizational research on job involvement. Psychological Bulletin, 84(2), 265-288. https://doi.org/10.1037/0033-2909.84.2.265

Rahardjo, B. (2014). Analisis Faktor Untuk Mengetahui Pengaruh Personal Selling dan Word of Mouth Tehadap Keputusan Pembelian Suatu Studi Kasus Pada PT. Starmas Inti Alumunium Industry. Jurnal Fakultas Ekonomi Universitas Budi Luhur Jakarta, 12(1), 12.

Rainayee, R. (2012). Organization, Job, Perks and Employee Turnover Intention. Abhinav International Monthly Refereed Journal of Research In Management \& Technology. ISSN: 2320.

Ramli, A. H. (2019). Manage of Job Stress and Measure Employee Performance in Health Services. Business and Entrepreneurial Review, 18(1), 53. https://doi.org/10.25105/ber.v18i1.5307

Riggio, R. E., Zhu, W., Reina, C., \& Maroosis, J. A. (2010). Virtue-based measurement of ethical leadership: The leadership virtues questionnaire. Consulting Psychology Journal, 62(4), 235-250. https://doi.org/10.1037/a0022286

Rivai, et al. (2012). Kepemimpinan dan Perilaku Organisasi (Edisi 3). Jakarta : Penerbit PT. Raja Grafindo Persada.

Robbins, S. P, \& Judge, T. (2006). Perilaku organisasi. Jakarta : PT Indeks Kelompok Gramedia.

Robbins, SP, H. T. (2014). Perilaku Organisasi. Salemba Empat.

Robbins. (2010). Manajemen. Jakarta : Erlangga.

Robbins, S. (2007). Perilaku Organisasi. (Edisi 10). PT Indeks : Kelompok Gramedia.

Robbins, S. P. (2013). Perilaku organisasi. Jakarta: PT. Indeks Kelompok Gramedia.

Robbins s.p \& m Coulte. (2007). Manajemen (Edisi 8). Jakarta : PT Indeks. Jakarta.

Rohman, M. L. (2018). Analisis Pengaruh Stres Kerja dan Job Insecurity Terhadap Turnover Intention dengan Komitmen Organisasional sebagai Variabel Intervening di PT. Kebon Agung Pabrik Gula Trangkil, Kabupaten Pati, Jawa Tengah.

Rohman, M. L. (2020). Analisis Pengaruh Stres Kerja dan Job Insecurity terhadap Turnover Intention dengan Komitmen Organisasional Sebagai Variabel Intervening di PT. Kebon Agung Pabrik Gula Trangkil, Kabupaten Pati, Jawa Tengah.

Rosi, Z. (2020). Pengaruh Stres Kerja Dan Kepuasan Kerja Terhadap Turnover Intention Yang Dimediasi Komitmen Organisasi ( Studi Kasus pada PT. Kemilau Bintang Timur Cirebon ).

Safrizal, M. (2014). Pengaruh Job Involvement Terhadap Turnover Intention Melalui Komitmen Organisasi Sebagai Variabel Mediasi. Paper Knowledge . Toward a Media History of Documents.

Santoso, S. (2011). Structural Equation Modeling, Konsep dan Aplikasi dengan AMOS 18.0. Jakarta: PT. Alex Media Komputindo.

Schaufeli, W. B., Bakker, A. B., \& Salanova, M. (2006). The measurement of work engagement with a short questionnaire: A cross-national study. Educational and Psychological Measurement, 66(4), 701716. https://doi.org/10.1177/0013164405282471

Schaufuli, W. B., Martínez, I. M., Pinto, A. M., Salanova, M., \& Barker, A. B. (2002). Burnout and engagement in university students a cross-national study. Journal of Cross-Cultural Psychology, 33(5), 464-481. https://doi.org/10.1177/0022022102033005003 
Septiari, N. K., \& Ardana, I. K. (2016). Pengaruh Job Insecurity Dan Stres Kerja Terhadap Turnover Intention Karyawan Pada Hotel Asana Agung Putra Bali. E-Jurnal Manajemen. https://ocs.unud.ac.id/index.php/Manajemen/article/view/23229

Sewwandi, D. V. ., \& Perere, G. D. . (2016). The Impact of Job Stress on Turnover Intention : A Study of Reputed Apparel Firm in Sri Lanka. 3rd International HRM Conference, 3(1), 223-229.

Sharma, S. (1996). Applied Multivariate Techniques. New-York: John Wiley \& Sons, Inc.

Sheraz, A., Wajid, M., Sajid, M., Qureshi, W. H. (2014). Antecedent of Job Stress and its Impact on Employee's Job Satisfaction and Turnover Intention. International Journal of Learning \& Develpoment I, SSN 2164-.

Siswoyo Haryono. (2017). METODE SEM (Untuk Penelitian Manajemen) AMOS LISREL PLS (Edisi 1). Luxima Metro Media.

Soelton, M., \& Atnani, M. (2018). How Work Environment, Work Satisfaction, Work Stress on the Turnover Intention Affect University Management. Jurnal Manajemen Dan Bisnis Indonesia. http://fmi.or.id/jmbi/index.php/jurnal/article/view/178

Sopiah. (2008). Perilaku Organisasi. Yogyakarta : CV. Andi Offset.

Sugiono. (2013). metode penelitian pendidikan (pendekatan kuantitatif, kualitatif, dan $R \& D$ ). Alfabeta, $\mathrm{CV}$.

Sugiono. (2016). Metode penelitian kuantitatif dan kualitatif dan R\&D. Bandung : Alfabeta.

Sugiyono. (2007). Metode Penelitian Kualitatif. CV Alfabeta.

Sugiyono, S. (2018). Metode Penelitian Bisnis (E. 3 (ed.)). Bandung.

Suprayoga, \& T. (2001). Metode Penelitian Kualtatif. Bandung: Remaja Rosdakarya.

Supriyanto, A.S., Machfudz, M. (2010). Metodologi Riset Manajemen Sumber daya Manusia. UIN Maliki Press, Malang.

Syamsul bahri, fahkry zamzam. (2014). Model Penelitian Kuantitatif, Berbasis SEM-AMOS. CV Budi utama.

Takase, M. (2010). A concept analysis of turnover intention: Implications for nursing management. Collegian, 17(1), 3-12. https://doi.org/10.1016/j.colegn.2009.05.001

Tanjung, H. (2019). Pengaruh Keterlibatan Kerja Dan Kepuasan Kerja Terhadap Komitmen Organisasi Pegawai. Jurnal Humaniora, 4(2), 36-49.

Timothy A. Judge, R. S. (2010). Perilaku Organisasi. Jakarta: Salemba Empat.

Tnay, E., Othman, A. E. A., Siong, H. C., \& Lim, S. L. O. (2013). The influences of job satisfaction and organizational commitment on turnover intention. Procedia-Social and Behavioral .... https://www.sciencedirect.com/science/article/pii/S1877042813036689

Tulangow et al. (2018). the Effect of Job Stress, Work Environment and Workload on Employee Turnover Intention (Case Study At Pt. Wika Realty Manado). Jurnal EMBA: Jurnal Riset Ekonomi, Manajemen, Bisnis Dan Akuntansi, 6(1), 474-482. https://doi.org/10.35794/emba.v6i1.19270

Waluyo, M. (2016). Mudah Cepat Tepat Penggunaan Tools Amos Dalam Aplikasi (SEM). UPN Jatim, 126.

Waspodo, A., Handayani, N. C., \& ... (2013). Pengaruh kepuasan kerja dan stres kerja terhadap turnover intention pada karyawan pt. Unitex di bogor. JRMSI-Jurnal Riset .... http://journal.unj.ac.id/unj/index.php/jrmsi/article/view/780

Wicaksono, R. S. (2020). Work Engagement sebagai Prediktor Turnover Intention pada Karyawan Generasi Millennial di PT Tri-Wall Indonesia. Acta Psychologia, 2(1), 55-62.

Wijaya, T. (2009). Analisis SEM Untuk Penelitian Menggunakan AMOS. Yogyakarta: Universitas Atmajaya.

Wijayanti, T. E. (2017). Analisis Pengaruh Keterlibatan Kerja dan Komitmen Organisasional Terhadap Keinginan Karyawan Untuk Berpindah Dengan Etika Kerja Islam Sebagai Variabel Moderasi( Studi pada BNI Syariah Cabang Surakarta ). Ekonomi Dan Bisnis Islam.

Wulanfitri, eki et al. (2020). Pengaruh Job Insecurity, Kepuasan Kerja dan Stres Kerja Terhadap Turnover Intention dengan Komitmen Organisasi Sebagai Variabel Intervening pada PT Lumina. $6(1), 1-7$.

Yanuar. (2015). "Pengaruh Gaya Kepemimpinan Transformasional dan Budaya Organisasi terhadap Komitmen pegawai: Motivasi Kerja sebagai Variabel Intervening pada Karyawan Kantor Pusat PT Nindya Karya." Jurnal Magister Manajemen, 2(1), 78-87. 
Yulianto, W. (2020). Pengaruh Gaya Kepemimpinan Kepala Sekolah Dan Kecerdasan Spiritual Guru Terhadap Komitmen Kerja Guru Di Sekolah Dasar Yang Berbasis Islam Di Kecamatan JatisampurnaBekasi. Buana Pendidikan: Jurnal Fakultas Keguruan dan Ilmu Pendidikan, 16(30), 158-167.

Yulk, G. A. (2006). kepemimpinan dalam organisasi (Terjemahan). Jakarta: PT. Indeks.

Zaenal, et al. (2014). Manajemen Sumber Daya Manusia Untuk Perusahaan dari Teori Ke Praktik. Jakarta : PT Rajagrafindo Persada.

ZHANG, J.-C., ZHANG, W.-Q. L. A. Z.-Y., \& XIE, J. (2015). Organizational Commitment , Work Engagement, Person - Supervisor Fit, and Turnover Intention : Social Behavior and Personality, 43(10), 1657-1666.

Zhang, W, Meng, H., Yang, S., \& Liu, D. (2018). The influence of professional identity, job satisfaction, and work engagement on turnover intention among township health inspectors in China. International Journal of Environmental .... https://www.mdpi.com/1660-4601/15/5/988

Zhang, Wenjie, Meng, H., Yang, S., \& Liu, D. (2018). The influence of professional identity, job satisfaction, and work engagement on turnover intention among township health inspectors in China. International Journal of Environmental Research and Public Health, 15(5). https://doi.org/10.3390/ijerph15050988.

\section{Copyrights}

Copyright for this article is retained by the author(s), with first publication rights granted to the journal.

This is an open-access article distributed under the terms and conditions of the Creative Commons Attribution license (http://creativecommons.org/licenses/by/4.0/). 